\title{
РОЛЬ МЕДИЧНОГО ПРАВА, ЯК НАВЧАЛЬНОЇ ДИСЦИПЛІНИ, НА ФАКУЛЬТЕТІ ПІСЛЯДИПЛОМНОЇ ОСВІТИ ЛЬВІВСЬКОГО НАЦІОНАЛЬНОГО МЕДИЧНОГО УНІВЕРСИТЕТУ ІМЕНІ ДАНИЛА ГАЛИЦЬКОГО
}

\author{
Львівський національний медичний університет імені Данила Галицького, м. Львів, Україна
}

\begin{abstract}
Мета - висвітлення ролі вивчення медичними працівниками навчальної дисципліни «Медичне право України», з'ясування значення правового компоненту в медичній освіті на післядипломному рівні (на прикладі ФПдО лНМУ імені Данила Галицького).

Матеріали і методи. Для оцінки вивчення права в медицині застосовано соціальне опитування (анкетування слухачів і моніторинг їхніх знань).

Результати. Для сприяння покращенню якості медичної допомоги та підвищення правової обізнаності медичних працівників запропоновано, поряд із виключно медичними дисциплінами, навчальний курс «Медичне право» на факультеті післядипломної освіти Львівського національного медичного університету імені Данила Галицького.

Висновки. Впровадження інноваційної дисципліни дозволить опанувати основи медичного права, підвищить рівень правової обізнаності медичних працівників, налаштує медиків на гармонійні відносини між лікарем і пацієнтом та усуне ризики збільшення частки медичних справ у національній судовій практиці.
\end{abstract}

КЛЮчОВІ СЛОВА: медичне право, медична освіта, інноваційні освітянські інструменти, медико-правові знання медичного персоналу.

Медичне право як галузь права, наука і навчальна дисципліна в Україні інтенсивно розвивається, розширюється діапазон фрахівців, що освоюють дані знання, та відбувається інтеграція у світові тенденції цієї царини. В умовах сьогодення роль медичного права - регулятора суспільних відносин у такій винятково важливій ссрері, як охорона здоров'я, - стрімко зростає. Водночас аналіз юридичної практики в медицині показує, що вона $є$ неоднозначна, а подекуди контроверзійні положення чинних нормативно-правових актів, які сьогодні зустрічаються, дають підстави стверджувати про наявність низки проблем, породжених труднощами правозастосування і правореалізації моральнодеонтологічними колізіями, з якими зустрічаються спеціалісти при наданні медичної допомоги.

Враховуючи вищесказане, опанування навчального курсу «Медичне право України» $є$ необхідним сегментом комплексної підготовки й забезпечення високої кваліфікації медичних працівників, які будуть конкурентоздатними й адаптованими до викликів практичної медицини в контексті взаємин 3 іншими суб'єктами медичних правовідносин. 3-поміж набору компетентностей знання правових основ, нормативно-правової бази в царині охорони здоров'я для фрахівця-медика є обов'язковим, що і віднайшло своє нормативне підтвердження у Довіднику кваліфікаційних характеристик професій

(C) О.Є. Січкоріз, 2016 працівників. У випуску 78 «Охорона здоров'я», затвердженому наказом МО3 України від 29.03.2002 p. № 117, для лікарів усіх спеціальностей передбачено освоєння знань з основ права в медицині, чинного законодавства у сорері охорони здоров'я та інших нормативних документів [2;4].

На кафредрі організації і управління охороною здоров'я Львівського національного медичного університету імені Данила Галицького (ЛНМУ) у 2004 р. вперше в Україні було розроблено програму 3 «Медичного права» для слухачів фракультетів післядипломної освіти вищих медичних навчальних закладів та закладів післядипломної освіти МО3 України, затверджену МО3 України 27.09.2004 р., а в оновленому фрорматі - 7 грудня 2011 року.

24 квітня 2013 р. у ЛНМУ на фракультеті післядипломної освіти (ФДПО) було створено кафедру медичного права, яка сьогодні здійснює комплексний підхід до навчання на основі розроблених тематичних планів з медичного права для студентів і слухачів університету. Кафедра медичного права $€$ опорною кафедрою в Україні, а відтак закладає навчально-методичні підвалини для всіх вищих медичних навчальних закладів, здійснює державну освітянську традицію в опануванні цього навчального курсу.

В умовах сьогодення медичному працівнику необхідно володіти знаннями у сорері правового 
регулювання медичної діяльності, а також уміти захищати і відстоювати свої інтереси. Володіння необхідною правовою інформацією у сфері охорони здоров'я стоїть в одному ряду з професійними знаннями медичного працівника та дотриманням ним морально-етичних норм. При ознайомленні 3 Єдиним державним реєстром судових рішень і зверненнями громадян до МОЗ України за 2015 р. нами зроблено висновок, що найчастіше в закладах охорони здоров'я порушуються: право людини на медичну інформацію; права людини на згоду і на відмову від медичного втручання; право людини на таємницю про стан здоров'я; право людини на якісну медичну допомогу; право людини на свободу вибору в галузі охорони здоров'я (в аспекті вільного вибору лікаря та закладу охорони здоров'я).

Однією з причин, що зумовлює виникнення наведених вище порушень, є низька правова обізнаність медичних працівників, що зазначено в листі Міністерства юстиції України від 20.06.2011 р., де вказано, що більшість медичних працівників і навіть керівників закладів охорони здоров'я мають поверхневе уявлення про юридичну відповідальність, яка встановлена чинним законодавством за правопорушення у сорері охорони здоров'я [5]. Отже для медичних працівників є вкрай необхідним отримання знань у сорері юридичного забезпечення медичної практики, що буде слугувати превенцією порушень прав людини у сорері охорони здоров'я.

Мета дослідження: висвітлити роль вивчення медичними працівниками навчальної дисципліни «Медичне право України», з'ясувати значення правового компоненту в медичній освіті на післядипломному рівні (на прикладі ФПДО лНМУ).

Матеріали і методи. Застосовано соціальне опитування, а саме анкетування слухачів і моніторинг їхніх знань для оцінки вивчення права в медицині.

Результати дослідження та їх обговорення. На кафедрі медичного права ФПдО ЛНМУ медичні працівники мають можливість поглибити свої знання, опанувавши курс «Медичне право України» при проходженні циклів спеціалізації та тематичного удосконалення. У процесі навчання слухачі набувають відповідних знань, зокрема щодо історії становлення юридичної регламентації медичної практики в Україні; конституційного регулювання прав людини у сфері охорони здоров'я в Україні; загального і спеціального законодавства у сорері охорони здоров'я; видів юридичної відповідальності за професійні правопорушення в окресленій царині; прав та обов'язків суб'єктів медичних правовідносин (пацієнтів, медичних працівників, законних представників пацієнта тощо); десектів надання медичної допомоги; ятрогенної патології та її медико-правового значення; правового регулювання сімейної медицини в Україні; правового регулювання надання психіатричної допомоги; юридичних аспектів просрілактики і лікування інсрекційних хвороб; законодавчого забезпечення донорства (крові, тканин, репродуктивних клітин); правового регулювання паліативної допомоги; законодавчої регламентації проведення медико-біологічних експериментів; регулювання експертної діяльності за законодавством України; особливостей правового забезпечення населення лікарськими засобами.

Крім того, на ФПДО ЛНМУ здійснено інноваційний крок у плані розширення надання освітянських послуг. Із січня 2016 р. на кафедрі медичного права детально вивчати навчальну дисципліну «Медичне право України» можуть юристи, які працюють у системі охорони здоров'я, а також викладачі-юристи, які викладають зазначену дисципліну в медичних вищих навчальних закладах. Ці інноваційні освітянські інструменти були впроваджені з метою системного підходу до зміни парадигми місця правового компоненту в медичній освіті. Такий комплекс заходів сприятиме спектральному підвищенню рівня правової обізнаності фрахівців, які працюють у системі охорони здоров'я. Тому що, незважаючи на певний крок у підготовці медичних кадрів, сьогоднішній рівень медико-правових знань медичного персоналу залишається невисоким. I це попри те, що до працівників системи охорони здоров'я висуваються вимоги стосовно знань основ чинного законодавства України про охорону здоров'я, нормативно-правових актів, які регламентують діяльність органів управління і закладів охорони здоров'я, основ права в медицині, правил офрормлення медичної документації тощо.

Для покращення і більшого розуміння вагомості отриманих знань з медичного права перед початком проходження курсів з тематичного удосконалення на кафедрі медичного права ФПДО ЛНМУ слухачам пропонується відповісти на запитання, що містяться в анкеті, розробленій 3 метою визначення в подальшому рівня знань з дисципліни «Медичне право України», які вони отримують на курсах, і з'ясування питань самоосвіти слухачів. Власне щодо останнього, то 70\% практичних лікарів майже не користуються фраховою періодичною літературою для підвищення свого професійного зросту, не знайомі з науковими працями з медичного права, що негативно відбивається на загальній правовій культурі фрахівців. Оскільки і юридична, і медична практики переконливо свідчать, що чим вищий рівень правової культури лікарів, тим ретельніше вони виконують свої профресійні обов'язки, тим вища якість і ефективність медичної допомоги населенню, тим реальніше забезпечуються права і законні інтереси людини у сорері охорони здоров'я.

Результати анкетувань слухачів і моніторингу їхніх знань наведені на рис.1-4.

Аналіз анкет слухачів і моніторинг їхніх знань показав, що самооцінка слухачів, які брали участь в анкетуванні, здійснювалась до вивчення навчальноїдисципліни, азріззнаньпроводивсяпісля 
Медичні працівники

відмінно $\|$ добре задовільно ш незадовільно

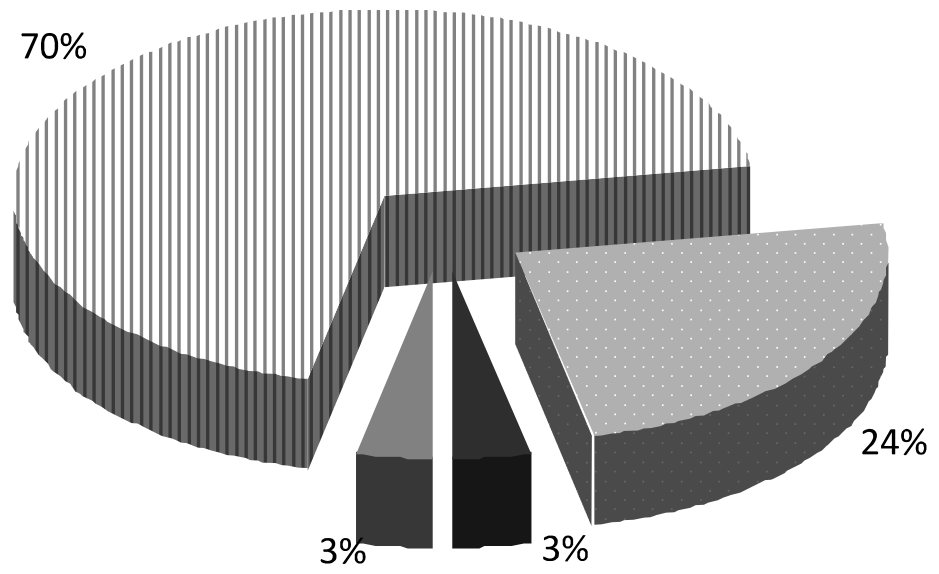

Puc.1. Самооцінка знань слухачів курсів тематичного удосконалення з дисципліни «Медичне право України»

Медичні працівники

відмінно |II добре задовільно незадовільно

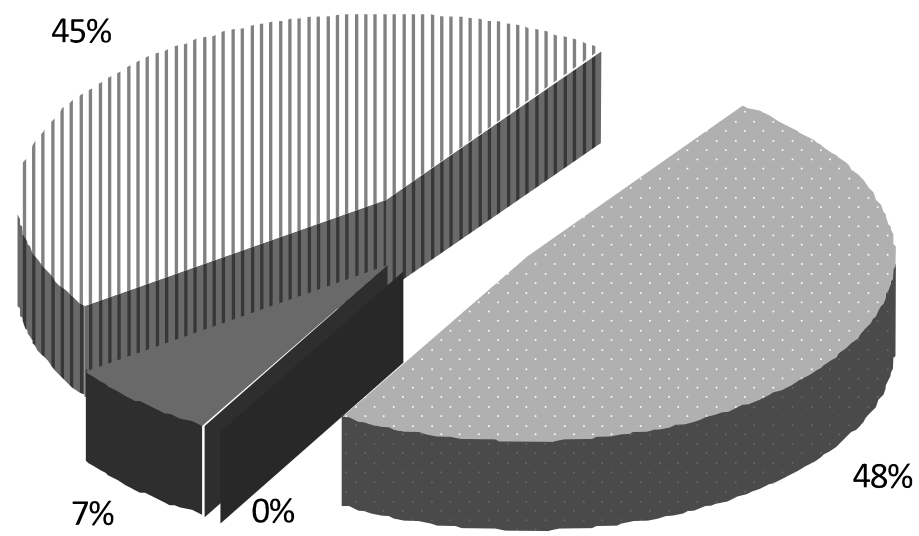

Puc.2. Фактична оцінка знань слухачів курсів тематичного удосконалення з дисципліни «Медичне право України»

Юристи, які працюють у системі охорони здоров'я

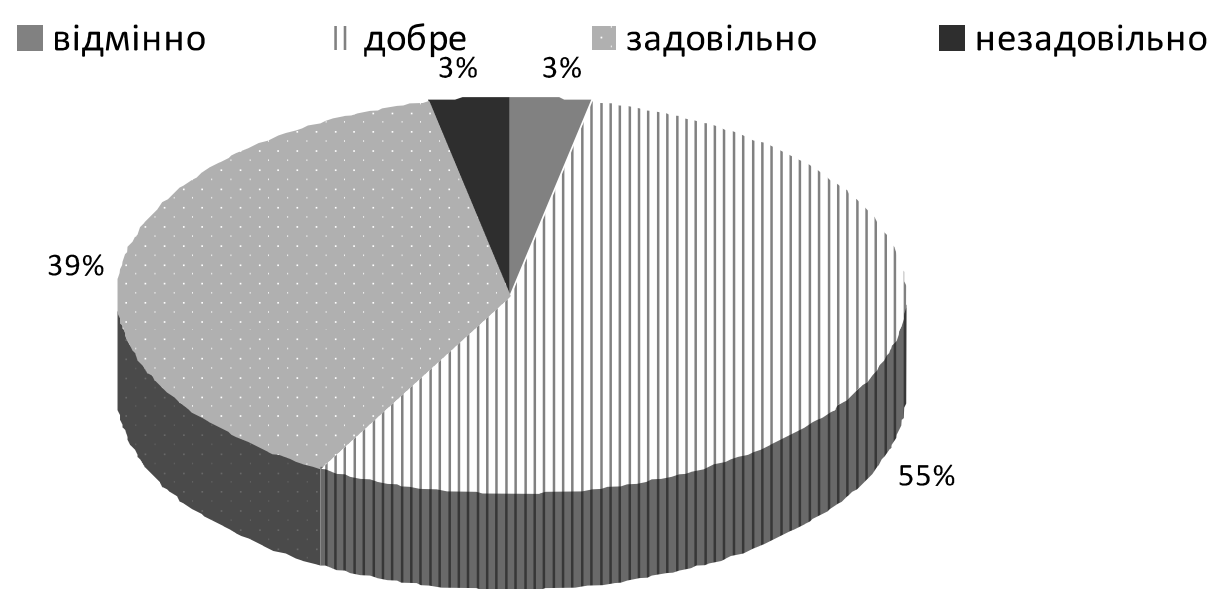

Рис.3. Самооцінка знань слухачів курсів тематичного удосконалення 3 дисципліни «Медичне право України» 
Юристи, які працюють у системі охорони здоров'я

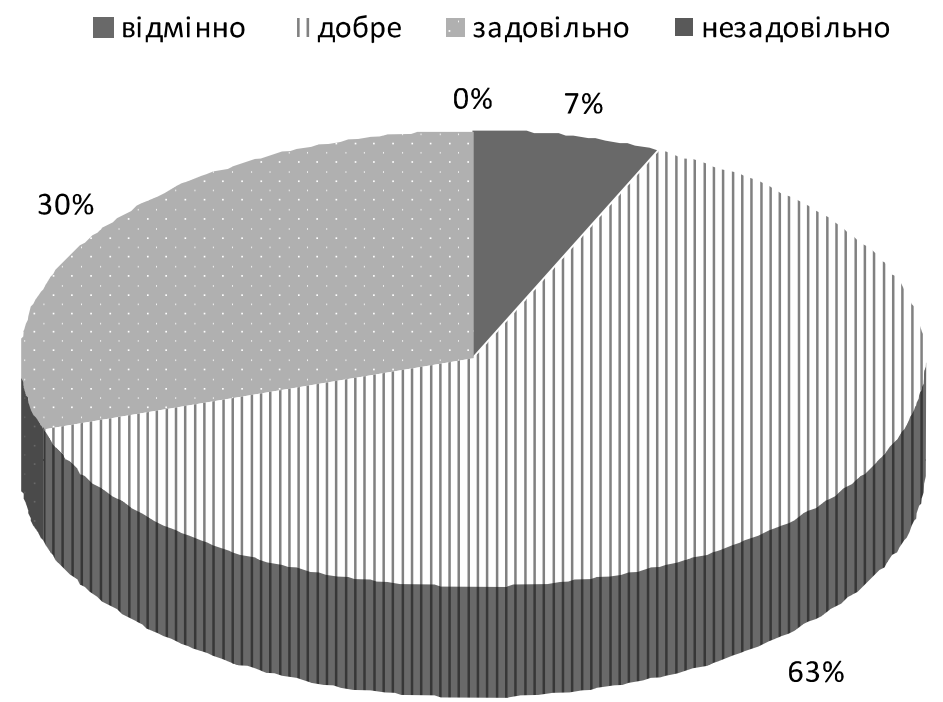

Puc.4. Фактична оцінка знань слухачів курсів тематичного удосконалення з дисципліни «Медичне право України»

опанування дисципліни з медичного права. Як видно, самооцінка різниться від оцінки за результатами зрізу знань, що повинно спонукати фрахівців до самоосвіти, самостійної роботи над поглибленням, зокрема, рівня своїх правових знань. Окрім того, інформація на діаграмах дає підстави стверджувати, що рівень знань після проходження циклів зростає, що вказує на важливість впливу навчального процесу в правовому векторі.

3 метою з'ясування засвоєння слухачами тематики медичного права після завершення навчання заповнювалась іще одна анкета. Після аналізу 58 анкет медичних працівників нами виокремлено питання, що найбільше зацікавили слухачів (рис. 5) та, навпаки, породили менший інтерес (рис. 6).
Отримані анкетні дані враховуються при викладі матеріалу, проте, щоб забезпечити повноту змістового наповнення навчальної дисципліни, здійснюється цілісне її опанування. Вивчення права в медицині, яке так необхідне для нашого суспільства, ґрунтується на основних чинниках ризику сьогодення:

- превенція у професійній діяльності, оскільки надається інфрормація, що слугує попередженню вчинення правопорушень, дотриманню прав пацієнтів, а також фрормуванню упевненості при провадженні медичної практики;

- численні ситуації, що виникають при провадженні медичної діяльності, мають юридичний фрон;

- можна ствердно говорити про збільшення частки медичних справ у національній судовій практиці;

правила роботи із зверненнями громадян

новели трудового законодавства

осообливості крймінальної відпіовідаліності у сфері охорони здоров’я

антикорупційне законодавство

правові аспекти захисту честі, гідності та ділової репутації медичного працівника господарська діяльність закладів охорони здоров'я

особливості захисту персональних даних

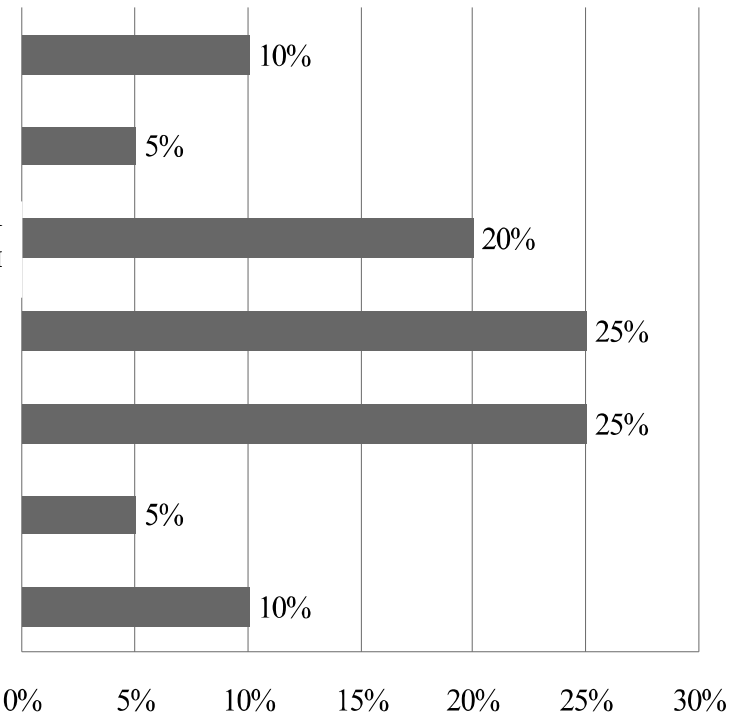

PUс.5. Питання, які найбільше зацікавили слухачів курсу «Медичне право України» 


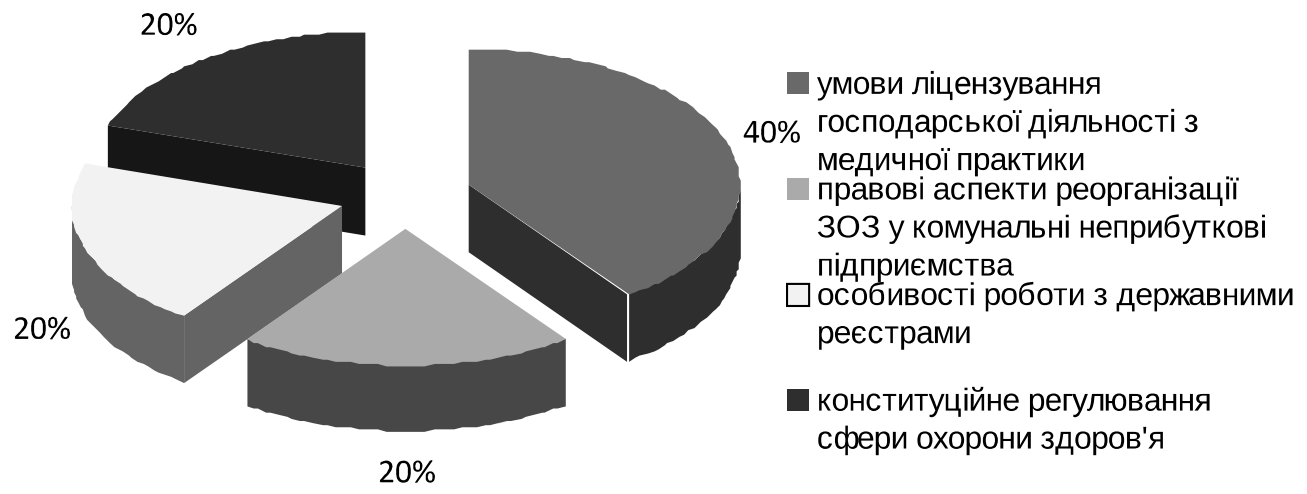

Puc.6. Питання, які викликали менший інтерес у слухачів курсу «Медичне право України»

- підвищення рівня правової обізнаності медичних працівників;

- налаштування медиків на гармонійні відносини лікар-пацієнт, що ґрунтуватимуться на біоетичних і правових засадах, сприятимуть підвищенню довіри до профресії.

\section{Висновки}

Знання основ правової регламентації медичної діяльності $\epsilon$ необхідним елементом успішної підготовки кожного медичного працівника, яка здійснюється шляхом вивчення основ медичного права на всіх рівнях підготовки медичних спеціалістів.

Новітня дисципліна в структурі післядипломної освіти все активніше обіймає свої позиції, поетапно розширюючи інстанційні простори та цільові аудиторії. Звичайно, є ще певні методологічні колізії, літературні прогалини, відчувається брак фрахівців, які мають належний обсяг знань для викладання цієї дисципліни, проте поступові освітянські зміни сприятимуть тому, що підготовка конкуренто- здатних, готових до викликів медичної практики, забарвленої юридичними проблемами, фрахівців стане українською традицією в усіх вищих медичних навчальних закладах.

Перспективи подальших досліджень. Науковий пошук щодо окресленого кола питань продовжується, адже дослідники вивчають навчальний компонент як ретроспективно, так і в аспекті стратегії розвитку навчальної дисципліни. Цікавим видається з'ясування доцільності опанування медичного права іншими цільовими групами, наприклад працівниками поліції, до кола повноважень яких, згідно із ст. 23 Закону України «Про Національну поліцію», належить вживання всіх можливих заходів для надання невідкладної, зокрема домедичної і медичної, допомоги особам, які постраждали внаслідок кримінальних чи адміністративних правопорушень, нещасних випадків, а також особам, які опинилися в ситуації, небезпечній для їхнього життя чи здоров'я.

\section{Список літератури}

1. Відповідальність медичних працівників : лист Міністерства юстиції України, Департамент конституційного, адміністративного та соціального законодавства управління соціального, трудового та гуманітарного законодавства від 20.06.2011 р. // Медичне право. - 2011. - № 8 (II). - С. 92.

2. Довідник кваліфікаційних характеристик професій працівників. Випуск 78 «Охорона здоров'я»: наказ МОЗ України від 29.03.2002 р. № 117 [Електронний ресурс]. - Режим доступу http://www.moz.gov.ua. - Назва з екрану.

3. Медичне право України : програма для слухачів фракультетів післядипломної освіти вищих медичних навчальних закладів та закладів післядипломної освіти МОЗ України / уклали І. Сенюта, О. Січкоріз. - Львів : Видавництво ЛОБФ «Медицина і право», 2012. - 98 с.

4. Про внесення змін до Довідника кваліфікаційних характеристик профресій працівників. Випуск 78 «Охорона здоров'я» : наказ МОЗ України від 12.08.2016 р. №720 [Електронний ресурс]. - Режим доступу http://www.moz.gov.ua. Назва з екрану.

5. Січкоріз О. Є. Досвід викладання циклу «Медичне право України» у Львівському національному медичному університеті імені Данила Галицького / О. Є. Січкоріз // Збірник матеріалів всеукраїнської науково-практичної конфреренції [«Теоретико-правові засади фрормування сучасного медичного права в Україні»] (26-27 жовтня 2012 р., м. Полтава). - С. 161-164.

\section{References}

1. Vidpovidalnist medychnykh pratsivnykiv. Lyst Ministerstva yustytsii Ukrainy. Departament konstytutsiynoho, administratyvnoho ta sotsialnoho zakonodavstva upravlinnya sotsialnoho, trudovoho ta humanitarnoho zakonodavstva vid 20.06.2011 r. [Responsibility of medical professionals: Letter of Ministry of Justice of Ukraine (Department of Constitutional, Administrative and Social Legislation of Social, Labour and Humanitarian Legislation Administration) 20 June 2011]. (n.d.). Medychne pravo - Medical Law, 8 (II), 92 [in Ukrainian]. 
2. Dovidnyk kvalifikatsiynykh kharakterystyk profesiy pratsivnykiv [Reference book on qualification characteristics of professions]. Nakaz MOZ Ukrainy vid 29.03.2002 r. № 117 [Order of Ministry of Health care of Ukraine No 117, from March, 29, 2002]. Okhorona zdorovya - Health care, Issue 78. Retrieved from www.moz.gov.ua [in Ukrainian].

3. Nakaz MOZ Ukrainy vid 12.08.2016 roku №720 Pro vnesennya zmin do Dovidnyka kvalifikatsiynykh kharakterystyk profesiy pratsivnykiv [Order of Ministry of Health care of Ukraine from August 12, 2002, № 720 On changes in the Reference book on qualification characteristics of professions]. Okhorona zdorovya - Health care, 78 [in Ukrainian].

4. Senyuta, I. \& Sichkoriz, O. (2012). Medychne pravo Ukraiiny [Medical law of Ukraine]. Prohrama dlya slukhachiv fakultetiv pislyadyplomnoi osvity vyshchykh medychnykh navchalnykh zakladiv ta zakladiv pislyadyplomnoi osvity $\mathrm{MOZ}$ Ukrainy [Syllabus for trainees of postgraduate education faculties of higher medical establishments and postgraduate establishments of Ministry of Health care of Ukraine]. Lviv: LOBF «Medytsyna i pravo» [in Ukrainian].

5. Sichkoriz, O.Ye. (2012). Dosvid vykladannya tsyklu «Medychne pravo Ukrainy» u Lvivskomu natsionalnomu medychnomu universyteti imeni Danyla Halytskoho [Experience of teaching the cycle "Medical law of Ukraine"]. Teoretyko-pravovi zasady formuvannya suchasnoho medychnoho prava v Ukrayini - Theoretical and Legislative Basics of Establishing Contemporary Medical Law in Ukraine: Proceedings of the All-Ukrainian scientific and practical Conference (pp. 161-164). Poltava [in Ukrainian].

\section{РОЛЬ МЕДИЦИНСКОГО ПРАВА, КАК УЧЕБНОЙ ДИСЦИПЛИНЫ, НА ФАКУЛЬТЕТЕ ПОСЛЕДИПЛОМНОГО ОБРАЗОВАНИЯ ЛЬВОВСКОГО НАЦИОНАЛЬНОГО МЕДИЦИНСКОГО УНИВЕРСИТЕТА ИМЕНИ ДАНИЛА ГАЛИЦКОГО \\ О.Е. Сичкориз}

Львовский национальный медицинский университет имени Данила Галицкого, г. Львов, Украина

Цель - освещение роли изучения медицинскими работниками учебной дисциплины «Медицинское право Украины», определение значения правового компонента в медицинском образовании на последипломном этапе (на примере фракультета последипломного образования Львовского национального медицинского университета имени Данила Галицкого).

Материалы и методы. Для оценки изучения права в медицине применен социальный опрос (анкетирование слушателей и мониторинг их знаний).

Результаты. Для содействия улучшению качества медицинской помощи и повышения правовой грамотности медицинских работников предложен, наряду с исключительно медицинскими дисциплинами, учебный курс «Медицинское право» на фракультете последипломного образования Львовского национального медицинского университета имени Данила Галицкого.

Выводы. Внедрение инновационной дисциплины позволит овладеть основами медицинского права, повысит уровень правовой грамотности медицинских работников, настроит медиков на гармоничные отношения между врачом и пациентом и устранит риск увеличения доли медицинских дел в национальной судебной практике.

КЛЮЧЕВЫЕ СЛОВА: медицинское право, медицинское образование, инновационные образовательные инструменты, медико-правовые знания медицинского персонала.

\section{ROLE OF MEDICAL LAW AS A COURSE OF STUDY AT POSTGRADUATE EDUCATION FACULTY OF DANYLO HAYTSKY LVIV NATIONAL MEDICAL UNIVERSITY}

\section{O.Y. Sichkoriz}

Danylo Halytsky Lviv National Medical University, Lviv, Ukraine

Aim. To highlight the role of studying the subject "Medical law of Ukraine", to clarify the significance of legislative component in medical education at postgraduate level (on the example of Postgraduate Education Faculty at Danylo Halytsky Lviv National Medical University).

Materials and methods. A social questioning (questionnaire study of trainees and monitoring their knowledge) was applied to assess studying of law in medicine.

Outcomes. The new course "Medical law" is offered for studying along with medical disciplines at the Faculty of Postgraduate education at DanyloHalytskyLviv National Medical University to promote quality improvement of health care and enrichment of legislative knowledge of medical professionals.

Conclusions. The implementation ofthe innovative course of study will facilitateacquiringmedical law basics, enhance level of legislative knowledge of medical staff, prepare medical professionals for harmonious physicianpatient relationship, and prevent risks for increasing number of medical cases in national legislative practice.

KEY WORDS: medical law, medical education, innovative educational tools, medical and legislative knowledge of medical staff.

Рукопис надійшов до редакції 16.01.2017

\section{Відомості про автора:}

Січкоріз Орест Євгенович - к.мед.н., декан фракультету післядипломної освіти, доцент кафедри дитячих інфекційних хвороб Львівського національного медичного університету імені Данила Галицького; тел.. служб. :+38 (032)276-93-74. 